Published in final edited form as:

Hear Res. 2008 January ; 235(1-2): 1-7.

\title{
Purinergic signaling in the inner ear
}

\author{
Jun Ho Lee ${ }^{\mathrm{a}}$ and Daniel C Marcus ${ }^{\mathrm{b},{ }^{*}}$ \\ aDepartment of Otorhinolaryngology, Seoul National University College of Medicine, Seoul National \\ University Hospital, 28 Yeongon-dong, Chongro-gu, Seoul 110-744, Korea
}

bDepartment of Anatomy and Physiology, Kansas State University, 1600 Denison Ave., Manhattan, KS 66506-5802, USA

\begin{abstract}
Epithelial cells of the inner ear coordinate their ion transport activity through a number of mechanisms. One important mechanism is the autocrine and paracrine signaling among neighboring cells in the ear via nucleotides, such as adenosine, ATP and UTP. This review summarizes observations on the release, detection and degradation of nucleotides by epithelial cells of the inner ear. Purinergic signaling is thought to be important for endolymph ion homeostasis and for protection from over stimulation.
\end{abstract}

\section{Keywords}

cochlea; vestibular labyrinth; purinergic receptor; stria vascularis; marginal cell; vestibular dark cell; nucleotide release; ATP; UTP; ecto-nucleotidase

\section{Introduction}

The inner ear consists of the peripheral organs of hearing (cochlea) and balance (vestibular labyrinth) (Fig. 1). These organs are comprised of epithelial cells that need to coordinate their transepithelial transport activity in both the presence and absence of mechanical stimuli, as well as in the face of systemic and local environmental challenges. Many of these cells do not have cell-to-cell gap junction communication (Kikuchi et al., 1994;Kikuchi et al., 1995) and therefore must rely on other signals to coordinate their activity. Nucleotides and their purinergic receptors appear to form the basis of important paracrine and autocrine communication systems in the inner ear. Hormonal signaling pathways consist of the controlled release of agonist from a cellular source, the receptors for the agonist and a termination mechanism that degrades or otherwise inactivates the agonist. There is evidence for the existence of all of these elements in purinergic signaling pathways in the inner ear. Further, there is evidence that the cochlear purinergic signaling systems are activated by acoustic stimulation.

\section{Sources of agonists}

Three possible sites have been identified for the sources of adenosine triphosphate (ATP) in the inner ear; 1) strial marginal cells and vestibular dark cells, 2) connexin hemichannels in cochlear supporting cells, 3) cells in the organ of Corti. White et al. (1995) have demonstrated

*Corresponding Author: Daniel C. Marcus, D.Sc., Kansas State University, Anatomy and Physiology, 126 Coles Hall, 1600 Denison Ave, Manhattan, KS 66506-5802, Tel.: +1 785532 4532, fax.: +1 785532 4557, E-mail: marcus@ksu.edu.

Publisher's Disclaimer: This is a PDF file of an unedited manuscript that has been accepted for publication. As a service to our customers we are providing this early version of the manuscript. The manuscript will undergo copyediting, typesetting, and review of the resulting proof before it is published in its final citable form. Please note that during the production process errors may be discovered which could affect the content, and all legal disclaimers that apply to the journal pertain. 
vesicles in close proximity to the apical membrane of marginal cells that reside in the stria vascularis. These vesicles stained with quinacrine, an acridine compound that binds to adenine nucleotides, particularly ATP (White et al., 1995). The morphological study by electron microscopy revealed that most of the vesicular structures were located within a layer 2-4 $\mu \mathrm{m}$ from the luminal or endolymphatic surface (White et al., 1995). In the lateral wall, the vesicular fraction of membrane-bound ATP was significantly greater $(2.02 \mathrm{nmol} \mathrm{ATP} / \mathrm{mg}$ protein) than the amount in the organ of Corti (0.69 nmol ATP/mg protein) (Munoz et al., 2001). There is as yet no direct evidence in vestibular dark cells; however, considering the functional homology between strial marginal cells and vestibular dark cells (Wangemann, 1995), it would be a likely site for ATP release in the vestibular labyrinth. $\mathrm{Ca}^{2+}$-dependent release of ATP has also been observed in the organ of Corti in vitro measured with a luciferase bioluminescence assay (Wangemann, 1996), although no vesicular storage of ATP has been identified there. Recently, connexin gap junctional hemichannels in supporting cells of the organ of Corti have been proposed as a possible source of ATP in the cochlea (Zhao et al., 2005). Gap junctions provide a diffusion pathway between adjacent cells by alignment of hemichannels composed of connexin subunits in each adjacent cell to form an open barrel structure connecting the cytosol of the two cells. However, the individual hemichannels can also occur in the plasma membrane at sites that do not connect to adjacent cells and therefore can provide a diffusion pathway between the cytosol and the extracellular fluid. Hemichannels can pass many small molecules up to about $1 \mathrm{kDa}$, including nucleotides. Isoform-specific selectivity of hemichannels has been described (Ayad et al., 2006; Zhao, 2005).

In the mammalian inner ear, connexins are expressed extensively in nonsensory supporting cells around cochlear and vestibular hair cells, but not in hair cells (Kikuchi et al., 1994; Kikuchi et al., 1995; Kikuchi et al., 2000). The connexin hemichannels also reside in the nonjunctional plasma membrane surfaces (Kikuchi et al., 1995). Zhao et al. demonstrated that ATP release could be increased 3 to 5-fold from the isolated cochlea, exclusive of the lateral wall, by a reduction of extracellular $\mathrm{Ca}^{2+}$ or an increase in membrane stress using hypotonic extracellular solution to increase cell volume (maneuvers known to increase fractional open time of connexin hemichannels), and the increase could be prevented by gap junction blockers (Zhao et al., 2005). Uridine triphosphate (UTP) and ATP are released from many epithelial cells via exocytosis, anion channels, and via as-yet-unidentified pathways in response to osmotic and mechanical stress (Hisadome et al., 2002; Homolya et al., 2000; Lazarowski et al., 1997; Schwiebert and Zsembery, 2003). However, UTP release has not yet been demonstrated in the inner ear.

\section{Receptor distribution}

Purinergic receptors occur as ionotropic $(\mathrm{P} 2 \mathrm{X})$ and metabotropic $(\mathrm{P} 1$ and $\mathrm{P} 2 \mathrm{Y})$ receptors, in several isoforms. The ionotropic receptors are ligand- (purine-) gated ion channels (cation nonselective) that have no intermediate signaling between the agonist and the effector. On the other hand, the metabotropic receptors are coupled via heterotrimeric $\mathrm{G}$ proteins in the plasma membrane to phospholipase C (PLC), which generates 1,2-diacylglycerol (DAG) and inositol-1,4,5-triphosphate (InsP3). DAG leads via one branch of the pathway to activation and translocation of protein kinase C (PKC) from the cytosol to the plasma membrane and InsP3 leads via a second branch of the pathway to elevation of cytosolic $\left[\mathrm{Ca}^{2+}\right]$. The effectors respond to either the activated PKC or elevated $\left[\mathrm{Ca}^{2+}\right]$.

\section{Apical (endolymphatic side) receptors}

The primary $\mathrm{P} 2 \mathrm{X}$ receptor subtype found in cells lining the cochlear duct is the $\mathrm{P} 2 \mathrm{X}_{2}$ receptor (Xiang et al., 1999). P2X receptors in the apical membranes of cells lining the cochlear duct appear to mediate a protective decrease in the electrical driving force for acoustic transduction via a reduction in transepithelial resistance of the cochlear duct (Thorne et al., 2004). These 
receptors are clearly located on the apical membrane of cochlear duct cells since this reduction in resistance occurs upon injection of ATP into the lumen (Thorne et al., 2004). There is functional evidence for the presence of these channels on the apical membrane of Reissner's membrane (King et al., 1998), outer hair cells (Housley et al., 1992), outer sulcus cells and vestibular transitional cells (Lee et al., 2001) (Fig. 1A, C).

Munoz et al have shown that noise elicits an increase in ATP concentration in endolymph (Munoz et al., 2001). Further, they found that when ATP is injected into scala media it causes a rapid and reversible fall in the endocochlear potential and a concomitant decrease in hearing sensitivity (increase in compound action potential thresholds) (Munoz et al., 1999; Munoz et al., 1995). They recently have shown that this ATP-induced fall in endocochlear potential can be attributed to a shunt across the cochlear partition (measured as a fall in cochlear partition resistance) arising from a cation (principally $\mathrm{K}^{+}$) flux through ATP-gated ion channels (P2X receptors) present on the endolymphatic surface of epithelial cells lining scala media (Thorne et al., 2004). This is blocked by the $\mathrm{P} 2 \mathrm{X}$ receptor-selective antagonist pyridoxal-phosphate-6azophenyl-2',4'-disulfonic acid (PPADS) injected into scala media. Sustained noise exposure $\left(100-120 \mathrm{~dB}\right.$ SPL, white noise, over 6 hours) up-regulates expression of $\mathrm{P} 2 \mathrm{X}_{2}$ and increases ATP-stimulated currents in the outer hair cells (Wang et al., 2003). They conclude that this ATP-mediated shunt of the endocochlear potential represents an autocrine and/or paracrine regulatory control process, which provides long-term homeostatic control of cochlear sensitivity and protection from acoustic damage.

The outer sulcus cells and vestibular transitional cells absorb cations via two kinds of nonselective cation channels at the apical membrane (Fig. 1D): ATP-sensitive (P2X $\left.\mathrm{X}_{2}\right)$ (Lee et al., 2001) and ATP-insensitive channels (Chiba and Marcus, 2000). The activation of $\mathrm{P} 2 \mathrm{X}_{2}$ leads to open ATP-sensitive nonselective cation channels (Lee et al., 2001), a process thought to protect the ear from overstimulation (above). The ATP-insensitive channel helps maintain the low $\mathrm{Na}^{+}$and $\mathrm{Ca}^{2+}$ levels of endolymph (Marcus and Chiba, 1999). The basolateral $\mathrm{K}^{+}$ conductance establishes the driving force for cation absorption (Chiba and Marcus, 2001). $\mathrm{Na}^{+}$is removed across the basolateral membrane by $\mathrm{Na}^{+}, \mathrm{K}^{+}$-ATPase (Chiba and Marcus, 2001). Reissner's membrane also has $P 2 X_{2}$ receptors on the apical membrane, but these operate in parallel with $\mathrm{Na}^{+}$-selective epithelial sodium channels in the apical membrane (Lee and Marcus, 2003) rather than nonselective cation channels. Recent findings indicated that $\mathrm{P}_{2} \mathrm{Y}_{4}$ receptors are expressed in developing outer sulcus cells, and then down-regulated in the adult (Lee et al., 2007).

Homeostasis of the luminal fluid composition is also controlled by $\mathrm{P}_{2} \mathrm{Y}_{4}$ receptors in the apical membrane of strial marginal cells and vestibular dark cells of rodents (gerbil and rat) (Liu et al., 1995; Marcus et al., 2005; Marcus and Scofield, 2001; Marcus et al., 1998; Sage and Marcus, 2002). Activation of these receptors decreases the rate of $\mathrm{K}^{+}$secretion, which is mediated by the constellation of transporters illustrated in Fig. 1B. $\mathrm{K}^{+}$is taken up across the basolateral membrane of the strial marginal cells and vestibular dark cells by the $\mathrm{Na}^{+}, \mathrm{K}^{+}-$ ATPase ("Na+ ${ }^{+}$-pump") and the $\mathrm{Na}^{+}, \mathrm{K}^{+}, 2 \mathrm{Cl}^{-}$cotransporter ( $\mathrm{NKCC} 1$ ). $\mathrm{Na}^{+}$carried into the cell on the cotransporter is removed by the $\mathrm{Na}^{+}$-pump and $\mathrm{Cl}^{-}$carried into the cell on the cotransporter leaves by passive diffusion via a large $\mathrm{Cl}^{-}$conductance $(\mathrm{ClC}-\mathrm{K} / \mathrm{Barttin})$ in the basolateral membrane. $\mathrm{K}^{+}$taken up by both the $\mathrm{Na}^{+}$-pump and the cotransporter is secreted across the apical membrane by diffusion via KCNQ1/KCNE1 $\mathrm{K}^{+}$channels.

$\mathrm{K}^{+}$secretion is thought to be modulated by at least three purinergic pathways in rodent: 1) phosphorylation of the $\beta$-subunit of the apical $\mathrm{K}^{+}$channel by protein kinase $\mathrm{C}$ (PKC) (Marcus et al., 1998; Marcus et al., 1997); 2) inhibition directly by increased intracellular $\mathrm{Ca}^{2+}$ (Shen and Marcus, 1998) and 3) by altered levels of membrane phosphatidylinositol-4,5bisphosphate ( $\mathrm{PIP}_{2}$ ) levels (Cho et al., 2002; Loussouarn et al., 2003). First, the ATP-sensitive 
short circuit current (a manifestation of $\mathrm{K}^{+}$secretion) of the strial marginal cells and vestibular dark cells was shown to be mediated via PKC, which was consistent with prior reports that the apical $\mathrm{K}^{+}$channel (KCNQ1/KCNE1) activity is inhibited by phosphorylation of KCNE1, the $\beta$-subunit of the channel (Cho et al., 2002; Loussouarn et al., 2003). By contrast, guinea pig ion transport, as reflected by cochlear voltages, does not respond to luminal UTP and therefore is not likely regulated by $\mathrm{P}_{2} \mathrm{Y}_{4}$ or $\mathrm{P}_{2} \mathrm{Y}_{2}$ receptors (Munoz et al., 1999). This apparent discrepancy is likely due to the absence of a PKC phosphorylation consensus site sequence in this species (Marcus et al., 1998). It was demonstrated that the introduction of ATP into the endolymph of the guinea pig decreased the endocochlear potential and the cochlear partition resistance. However, these decreases in voltage and resistance were shown to be due to activation of P2X2 receptors, rather than P2Y4 receptors (Thorne et al., 2004).

Second, KCNQ1/KCNE1 $\mathrm{K}^{+}$channels in the strial marginal cells were shown to be inhibited by divalent ions, including $\mathrm{Ca}^{2+}$ (Shen and Marcus, 1998). The increase in cytosolic $\mathrm{Ca}^{2+}$ levels in response to apical ATP could therefore act directly on the channel activity.

Third, the decrease in $\mathrm{K}^{+}$secretion by luminal ATP or UTP is maintained for at least 15 min in the continued presence of agonist (Marcus et al., 2005) although both cloned $\mathrm{P} 2 \mathrm{Y}_{2}$ and cloned $\mathrm{P}_{2} \mathrm{Y}_{4}$ purinergic receptors have been reported to undergo desensitization within 5-15 min (Otero et al., 2000; Robaye et al., 1997). The most likely explanation for the apparent lack of desensitization (sustained decrease) of $\mathrm{K}^{+}$secretion in the inner ear is based on recent findings that activation of receptors (such as $\mathrm{P}_{2} \mathrm{Y}_{4}$ ) coupled to $\mathrm{G}_{\mathrm{q} / 11}$ deplete $\mathrm{PIP}_{2}$ (Cho et al., 2002) and that KCNQ1/KCNE1 $\mathrm{K}^{+}$channel activity is reduced by depletion of plasma membrane $\mathrm{PIP}_{2}$ (Loussouarn et al., 2003). $\mathrm{PIP}_{2}$ (phosphatidylinositol-4,5-bisphosphate) is a plasma membrane phospholipid that is normally a component of a second-messenger signaling cascade that results in the release of $\mathrm{IP}_{3}$ to the cytosol and release of $\mathrm{Ca}^{2+}$ from endoplasmic reticulum stores via $\mathrm{IP}_{3}$ receptors. Stimulation of such a signaling pathway would therefore deplete $\mathrm{PIP}_{2}$ in the plasma membrane when it is converted to $\mathrm{IP}_{3}$.

Interestingly, the depletion of $\mathrm{PIP}_{2}$ might be associated with the involvement of myristoylated alanine-rich C-kinase substrate (MARCKS). MARCKS is the major PKC substrate in most mammalian cells (McLaughlin and Murray, 2005). It was recently shown that MARCKS acts as a reversible $\mathrm{PIP}_{2}$ source in the plasma membrane, by electrostatically sequestering the negatively-charged $\mathrm{PIP}_{2}$. When the cytosolic $\left[\mathrm{Ca}^{2+}\right]$ increases, $\mathrm{Ca} / \mathrm{Calmodulin}$ binds to MARCKS with high affinity and pulls MARCKS off the membrane, releasing three $\mathrm{PIP}_{2}$ molecules (McLaughlin and Murray, 2005).

Thus, the pathways from $\mathrm{P}_{2} \mathrm{Y}_{4}$ stimulation converge (Figure 1): 1) G protein-PLC activation leads to consumption of membrane $\mathrm{PIP}_{2}$, with the consequent reduction in $\mathrm{K}^{+}$channel activity; 2) the DAG-PKC path decreases $\mathrm{K}^{+}$channel activity directly via phosphorylation of the channel; and 3) the IP3/ $\mathrm{Ca}^{2+}$ path decreases channel activity directly via the effect of $\mathrm{Ca}^{2+}$ on channel activity. The IP3/Ca ${ }^{2+}$ path also provides some recovery from $\mathrm{PIP}_{2}$ depletion via $\mathrm{Ca}^{2+} /$ calmodulin-MARKS.

\section{Basolateral (perilymphatic side) receptors}

Multiple P2 receptors in the basolateral membrane of the strial marginal cells and vestibular dark cells are known to contribute to homeostasis of the luminal fluid composition (Liu et al., 1995; Sage and Marcus, 2002). The ionic current produced across these epithelia is modulated in a biphasic manner by basolateral purinergic agonists. The receptor subtypes involved were tentatively identified as $\mathrm{P}_{2} \mathrm{Y}_{2}$ (Sage and Marcus, 2002) and $\mathrm{P} 2 \mathrm{Y}_{1}$, although a $\mathrm{P} 2 \mathrm{X}$ receptor has not been ruled out (Liu et al., 1995). Other evidence points to purinergic signaling in the organ of Corti; these $\mathrm{P} 2$ receptors do not likely contribute significantly to homeostasis of the luminal fluid composition but may influence the basolateral microenvironment of the inner 
hair cells (Dulon et al., 1991; Sugasawa et al., 1996), Deiters' cells, and Hensen's cells (Dulon et al., 1993). The sidedness of the location of the receptors in these cells is not positively established. The receptors on the Deiters' cells are likely P2Y and the receptors on the Hensen's cells are likely $\mathrm{P} 2 \mathrm{X}$, as evidenced by the involvement of internal $\mathrm{Ca}^{2+}$ stores in the former but not the latter cells.

\section{Termination}

Extracellular nucleotides can be inactivated by hydrolysis via ectonuleotidases located at the cell membrane. These include the E-NTPDase (ectonucleoside triphosphate diphosphohydrolase) family, the E-NPP (ectonucleotide pyrophosphatase/phosphodiesterase) family, ecto-5' -nucleotidase, and alkaline phosphatases (Zimmermann, 2001). The presence of ectonucleotidase was shown experimentally both in the endolymphatic (Vlajkovic et al., 1998a) and perilymphatic compartments (Vlajkovic et al., 1998b; Vlajkovic et al., 1996). Of six members of the E-NTPDase family, NTPDase 1, NTPDase 2, and NTPDase 3 are likely the key elements for termination of purinergic signaling in the cochlea (Vlajkovic et al., 1999; Vlajkovic et al., 2006). NTPDase 1 degrades both nucleoside triphosphates and diphosphates. In contrast, NTPDase 2 has preference for nucleoside triphosphate. NTPDase 3 is intermediate in terms of the nucleotide hydrolysis ratio (ATPase: ADPase activity) (Smith and Kirley, 1998). Immunohistochemical staining revealed the detailed location of NTPDase 1, 2, and 3 in the murine cochlea (Vlajkovic et al., 2002a; Vlajkovic et al., 2002b; Vlajkovic et al., 2006). The distribution of E-NTPDases in the cochlear vasculature, spiral ligament, spiral ganglion neuron, cuticular plate of inner and outer hair cells, and afferent dendritic synapse indicates that they involve a variety of cochlear physiologic processes in which purinergic $\mathrm{P} 2 \mathrm{X}$ and $\mathrm{P} 2 \mathrm{Y}$ receptors are expressed.

\section{Activation by noise and/or stress}

All three components of the mechanism of purinergic signaling (agonist, receptor, termination) in the cochlea can be activated by acoustic-overstimulation. The increase of agonist with noise was described above. Chronic noise exposure also upregulates $\mathrm{P}_{2} \mathrm{X}_{2}$ mRNA in cochlear hair cells, spiral ganglion (Wang et al., 2003), adenosine receptor in the cochlear tissues (Ramkumar et al., 2004), NTPDase 1 and 2 mRNA in the cochlea (Vlajkovic et al., 2004), and NTPDase 3 immunoreactivity at sites associated with auditory neurotransmission (Vlajkovic et al., 2006). NTPDase 1 and 2 was upregulated in the stria vascularis and NTPDase 2 in intraganglionic spiral bundle, but NTPDase 1 was down-regulated in spiral ganglion neurons (Vlajkovic et al., 2004).

\section{P1 (A) adenosine receptors}

There is a family of four adenosine receptors ( $\mathrm{P} 1$ receptors or $\mathrm{A}$ receptors) which have been cloned and characterized from several mammalian species. These include $A_{1}, A_{2 A}, A_{2 B}$, and $A_{3}$ (Fredholm et al., 2001). $A_{1}$ and $A_{3}$ receptors couple to $G_{i / 0}$-dependent pathway and inhibit adenylyl cyclase, and $\mathrm{A}_{2 \mathrm{~A}}$ and $\mathrm{A}_{2 \mathrm{~B}}$ receptors preferentially interact with the members of the Gs family of $G$ proteins. $A_{1}$ receptors have been identified in rat cochlear tissues using radioligand binding studies and RT-PCR (Ramkumar et al., 1994). Further, the expression level of $A_{1}$ and $A_{3}$ receptors was found to be higher in the well-vascularized cochlear lateral wall and organ of Corti than in the eighth nerve of chinchilla cochlea (Ford et al., 1997). Recently, mRNA transcripts for all four subtypes of adenosine receptors were detected in rat cochlear tissue, and adenosine receptors were found to be differentially expressed in the sensory hair cells and supporting cells of the organ of Corti, spiral ganglion neurons, and cochlear vasculature (Vlajkovic et al., 2007) 
Several studies have indicated the presence in cochlear tissues of adenosine receptors that are thought to be activated through generation of reactive oxygen species (ROS) in response to various stresses to the inner ear. Noise exposure induced $\mathrm{A}_{1}$ receptor expression, which might be mediated, in part, through generation of ROS and activation of nuclear factor (NF)-kB (Ramkumar et al., 2004). In particular, there is evidence that cochlear blood flow can be modulated by adenosine receptors. The application of adenosine to the perilymph (scala tympani) produced a dose-dependent increase in cochlear blood flow, as measured by a laser Doppler blood flow probe on the bone overlying the cochlear lateral wall (Thorne and Nuttall, 1987). Further, the agonist adenosine is released by ROS-generating systems, and attenuates the deleterious cellular consequences of ROS through A1 receptor activation (Almeida et al., 2003; Ramkumar et al., 2004). The P1 signal pathway therefore is likely a key player in protection of cochlear function from stresses such as cochlear hypoperfusion and ischemia, noise exposure, aging, and ototoxicity that are mediated by generation of ROS (Ohinata et al., 2000; Ohlemiller et al., 1999; Seidman et al., 1999; Yamashita et al., 2004).

\section{Acknowledgements}

This work was supported by NIH grant R01-DC00212 to DCM and by the Clinical Research Institute at Seoul National University Hospital (Grant No. 04-2007-036-0) to JHL.

\section{References}

Almeida CG, de Mendonca A, Cunha RA, Ribeiro JA. Adenosine promotes neuronal recovery from reactive oxygen species induced lesion in rat hippocampal slices. Neurosci Lett 2003;339:127-130. [PubMed: 12614911]

Ayad WA, Locke D, Koreen IV, Harris AL. Heteromeric, but not homomeric, connexin channels are selectively permeable to inositol phosphates. J Biol Chem 2006;281:16727-16739. [PubMed: 16601118]

Chiba T, Marcus DC. Nonselective cation and BK channels in apical membrane of outer sulcus epithelial cells. J Membr Biol 2000;174:167-179. [PubMed: 10742460]

Chiba T, Marcus DC. Basolateral $\mathrm{K}^{+}$conductance establishes driving force for cation absorption by outer sulcus epithelial cells. J Membr Biol 2001;184:101-112. [PubMed: 11719847]

Cho H, Hwang JY, Kim D, Shin HS, Kim Y, Earm YE, Ho WK. Acetylcholine-induced phosphatidylinositol 4,5-bisphosphate depletion does not cause short-term desensitization of G protein-gated inwardly rectifying K+ current in mouse atrial myocytes. J Biol Chem 2002;277:2774227747. [PubMed: 12019267]

Dulon D, Moataz R, Mollard P. Characterization of $\mathrm{Ca}^{2+}$ signals generated by extracellular nucleotides in supporting cells of the organ of Corti. Cell Calcium 1993;14:245-254. [PubMed: 8500138]

Dulon D, Mollard P, Aran JM. Extracellular ATP elevates cytosolic $\mathrm{Ca}^{2+}$ in cochlear inner hair cells. Neuroreport 1991;2:69-72. [PubMed: 1883987]

Ford MS, Maggirwar SB, Rybak LP, Whitworth C, Ramkumar V. Expression and function of adenosine receptors in the chinchilla cochlea. Hear Res 1997;105:130-140. [PubMed: 9083810]

Fredholm BB, IJzerman AP, Jacobson KA, Klotz KN, Linden J. International Union of Pharmacology. XXV. Nomenclature and classification of adenosine receptors. Pharmacol Rev 2001;53:527-552. [PubMed: 11734617]

Hisadome K, Koyama T, Kimura C, Droogmans G, Ito Y, Oike M. Volume-regulated Anion Channels Serve as an Auto/Paracrine Nucleotide Release Pathway in Aortic Endothelial Cells. J Gen Physiol 2002;119:511-520. [PubMed: 12034759]

Homolya L, Steinberg TH, Boucher RC. Cell to cell communication in response to mechanical stress via bilateral release of ATP and UTP in polarized epithelia. J Cell Biol 2000;150:1349-1360. [PubMed: 10995440]

Housley GD, Greenwood D, Ashmore JF. Localization of cholinergic and purinergic receptors on outer hair cells isolated from the guinea-pig cochlea. Proc R Soc Lond [Biol] 1992;249:265-273. 
Kikuchi T, Adams JC, Paul DL, Kimura RS. Gap junction systems in the rat vestibular labyrinth: Immunohistochemical and ultrastructural analysis. Acta Otolaryngol (Stockh) 1994;114:520-528. [PubMed: 7825434]

Kikuchi T, Kimura RS, Paul DL, Adams JC. Gap junctions in the rat cochlea: immunohistochemical and ultrastructural analysis. Anat Embryol (Berl) 1995;191:101-118. [PubMed: 7726389]

Kikuchi T, Kimura RS, Paul DL, Takasaka T, Adams JC. Gap junction systems in the mammalian cochlea. Brain Res Brain Res Rev 2000;32:163-166. [PubMed: 10751665]

King M, Housley GD, Raybould NP, Greenwood D, Salih SG. Expression of ATP-gated ion channels by Reissner's membrane epithelial cells. Neuroreport 1998;9:2467-2474. [PubMed: 9721916]

Lazarowski ER, Homolya L, Boucher RC, Harden TK. Direct demonstration of mechanically induced release of cellular UTP and its implication for uridine nucleotide receptor activation. J Biol Chem 1997;272:24348-24354. [PubMed: 9305892]

Lee JH, Chiba T, Marcus DC. P2X2 receptor mediates stimulation of parasensory cation absorption by cochlear outer sulcus cells and vestibular transitional cells. J Neurosci 2001;21:9168-9174. [PubMed: 11717350]

Lee JH, Heo JH, Kim CH, Chang SO, Kim CS, Oh SH. Changes in P2Y4 receptor expression in rat cochlear outer sulcus cells during development. Hear Res 2007;228:201-211. [PubMed: 17433586]

Lee JH, Marcus DC. Endolymphatic sodium homeostasis by Reissner's membrane. Neuroscience 2003;119:3-8. [PubMed: 12763062]

Liu J, Kozakura K, Marcus DC. Evidence for purinergic receptors in vestibular dark cell and strial marginal cell epithelia of the gerbil. Auditory Neurosci 1995;1:331-340.

Loussouarn G, Park KH, Bellocq C, Baro I, Charpentier F, Escande D. Phosphatidylinositol-4,5bisphosphate, PIP2, controls KCNQ1/KCNE1 voltage-gated potassium channels: a functional homology between voltage-gated and inward rectifier K+ channels. EMBO J 2003;22:5412-5421. [PubMed: 14532114]

Marcus DC, Chiba T. $\mathrm{K}^{+}$and $\mathrm{Na}^{+}$absorption by outer sulcus epithelial cells. Hear Res 1999;134:48-56. [PubMed: 10452375]

Marcus DC, Liu J, Lee JH, Scherer EQ, Scofield MA, Wangemann P. Apical membrane P2Y4 purinergic receptor controls K+ secretion by strial marginal cell epithelium. Cell Commun Signal 2005;3:13. [PubMed: 16266433]

Marcus DC, Scofield MA. Apical P2Y4 purinergic receptor controls $\mathrm{K}^{+}$secretion by vestibular dark cell epithelium. Am J Physiol Cell Physiol 2001;281:C282-C289. [PubMed: 11401851]

Marcus DC, Sunose H, Liu J, Bennett T, Shen Z, Scofield MA, Ryan AF. Protein kinase C mediates P2U purinergic receptor inhibition of $\mathrm{K}^{+}$channel in apical membrane of strial marginal cells. Hear Res 1998;115:82-92. [PubMed: 9472737]

Marcus DC, Sunose H, Liu J, Shen Z, Scofield MA. P2U purinergic receptor inhibits apical IsK/KvLQT1 channel via protein kinase C in vestibular dark cells. Am J Physiol 1997;273:C2022-C2029. [PubMed: 9435509]

McLaughlin S, Murray D. Plasma membrane phosphoinositide organization by protein electrostatics. Nature 2005;438:605-611. [PubMed: 16319880]

Munoz DJ, Kendrick IS, Rassam M, Thorne PR. Vesicular storage of adenosine triphosphate in the guinea-pig cochlear lateral wall and concentrations of ATP in the endolymph during sound exposure and hypoxia. Acta Otolaryngol 2001;121:10-15. [PubMed: 11270486]

Munoz DJ, Thorne PR, Housley GD. P2X receptor-mediated changes in cochlear potentials arising from exogenous adenosine 5'-triphosphate in endolymph. Hear Res 1999;138:56-64. [PubMed: 10575114]

Munoz DJ, Thorne PR, Housley GD, Billett TE, Battersby JM. Extracellular adenosine 5'-triphosphate (ATP) in the endolymphatic compartment influences cochlear function. Hear Res 1995;90:106-118. [PubMed: 8974987]

Ohinata Y, Miller JM, Altschuler RA, Schacht J. Intense noise induces formation of vasoactive lipid peroxidation products in the cochlea. Brain Res 2000;878:163-173. [PubMed: 10996147]

Ohlemiller KK, Wright JS, Dugan LL. Early elevation of cochlear reactive oxygen species following noise exposure. Audiol Neurootol 1999;4:229-236. [PubMed: 10436315] 
Otero M, Garrad RC, Velazquez B, Hernandez-Perez MG, Camden JM, Erb L, Clarke LL, Turner JT, Weisman GA, Gonzalez FA. Mechanisms of agonist-dependent and -independent desensitization of a recombinant P2Y2 nucleotide receptor. Mol Cell Biochem 2000;205:115-123. [PubMed: 10821429]

Ramkumar V, Ravi R, Wilson MC, Gettys TW, Whitworth C, Rybak LP. Identification of A1 adenosine receptors in rat cochlea coupled to inhibition of adenylyl cyclase. Am J Physiol 1994;267:C731C737. [PubMed: 7943201]

Ramkumar V, Whitworth CA, Pingle SC, Hughes LF, Rybak LP. Noise induces A1 adenosine receptor expression in the chinchilla cochlea. Hear Res 2004;188:47-56. [PubMed: 14759570]

Robaye B, Boeynaems JM, Communi D. Slow desensitization of the human P2Y6 receptor. Eur J Pharmacol 1997;329:231-236. [PubMed: 9226417]

Sage CL, Marcus DC. Immunolocalization of P2Y4 and P2Y2 purinergic receptors in strial marginal cells and vestibular dark cells. J Membr Biol 2002;185:103-115. [PubMed: 11891569]

Schwiebert EM, Zsembery A. Extracellular ATP as a signaling molecule for epithelial cells. Biochim Biophys Acta 2003;1615:7-32. [PubMed: 12948585]

Seidman MD, Quirk WS, Shirwany NA. Mechanisms of alterations in the microcirculation of the cochlea. Ann N Y Acad Sci 1999;884:226-232. [PubMed: 10842596]

Shen Z, Marcus DC. Divalent cations inhibit IsK/KvLQT1 channels in excised membrane patches of strial marginal cells. Hear Res 1998;123:157-167. [PubMed: 9745964]

Smith TM, Kirley TL. Cloning, sequencing, and expression of a human brain ecto-apyrase related to both the ecto-ATPases and CD39 ecto-apyrases1. Biochim Biophys Acta 1998;1386:65-78. [PubMed: 9675246]

Sugasawa M, Erostegui C, Blanchet C, Dulon D. ATP activates non-selective cation channels and calcium release in inner hair cells of the guinea-pig cochlea. J Physiol (Lond) 1996;491:707-718. [PubMed: 8815205]

Thorne PR, Munoz DJ, Housley GD. Purinergic modulation of cochlear partition resistance and its effect on the endocochlear potential in the Guinea pig. J Assoc Res Otolaryngol 2004;5:58-65. [PubMed: 14976588]

Thorne PR, Nuttall AL. Laser Doppler measurements of cochlear blood flow during loud sound exposure in the guinea pig. Hear Res 1987;27:1-10. [PubMed: 2953704]

Vlajkovic SM, Abi S, Wang CJ, Housley GD, Thorne PR. Differential distribution of adenosine receptors in rat cochlea. Cell Tissue Res 2007;328:461-471. [PubMed: 17285327]

Vlajkovic SM, Housley GD, Greenwood D, Thorne PR. Evidence for alternative splicing of ecto-ATPase associated with termination of purinergic transmission. Brain Res Mol Brain Res 1999;73:85-92. [PubMed: 10581401]

Vlajkovic SM, Housley GD, Munoz DJ, Robson SC, Sevigny J, Wang CJ, Thorne PR. Noise exposure induces up-regulation of ecto-nucleoside triphosphate diphosphohydrolases 1 and 2 in rat cochlea. Neuroscience 2004;126:763-773. [PubMed: 15183524]

Vlajkovic SM, Thorne PR, Housley GD, Munoz DJ, Kendrick IS. Ecto-nucleotidases terminate purinergic signalling in the cochlear endolymphatic compartment. Neuroreport 1998a;9:1559-1565. [PubMed: 9631467]

Vlajkovic SM, Thorne PR, Housley GD, Munoz DJ, Kendrick IS. The pharmacology and kinetics of ecto-nucleotidases in the perilymphatic compartment of the guinea-pig cochlea. Hear Res 1998b; 117:71-80. [PubMed: 9580435]

Vlajkovic SM, Thorne PR, Munoz DJ, Housley GD. Ectonucleotidase activity in the perilymphatic compartment of the guinea pig cochlea. Hear Res 1996;99:31-37. [PubMed: 8970811]

Vlajkovic SM, Thorne PR, Sevigny J, Robson SC, Housley GD. Distribution of ectonucleoside triphosphate diphosphohydrolases 1 and 2 in rat cochlea. Hear Res 2002a;170:127-138. [PubMed: 12208547]

Vlajkovic SM, Thorne PR, Sevigny J, Robson SC, Housley GD. NTPDase1 and NTPDase2 immunolocalization in mouse cochlea: implications for regulation of $\mathrm{p} 2$ receptor signaling. $\mathrm{J}$ Histochem Cytochem 2002b;50:1435-1442. [PubMed: 12417608] 
Vlajkovic SM, Vinayagamoorthy A, Thorne PR, Robson SC, Wang CJ, Housley GD. Noise-induced upregulation of NTPDase 3 expression in the rat cochlea: Implications for auditory transmission and cochlear protection. Brain Res 2006;1104:55-63. [PubMed: 16815340]

Wang JC, Raybould NP, Luo L, Ryan AF, Cannell MB, Thorne PR, Housley GD. Noise induces upregulation of $\mathrm{P} 2 \mathrm{X} 2$ receptor subunit of $\mathrm{ATP}$-gated ion channels in the rat cochlea. Neuroreport 2003;14:817-823. [PubMed: 12858039]

Wangemann P. Comparison of ion transport mechanisms between vestibular dark cells and strial marginal cells. Hear Res 1995;90:149-157. [PubMed: 8974992]

Wangemann P. $\mathrm{Ca}^{2+}$-dependent release of ATP from the organ of Corti measured with a luciferinluciferase bioluminescence assay. Auditory Neurosci 1996;2:187-192.

Wangemann P. Supporting sensory transduction: cochlear fluid homeostasis and the endocochlar potential. J Physiol 2006;576:11-21. [PubMed: 16857713]

Wangemann P. $\mathrm{K}^{+}$cycling and its regulation in the cochlea and the vestibular labyrinth. Audiol Neurootol 2002;7:199-205. [PubMed: 12097719]

White PN, Thorne PR, Housley GD, Mockett B, Billett TE, Burnstock G. Quinacrine staining of marginal cells in the stria vascularis of the guinea-pig cochlea: a possible source of extracellular ATP? Hear Res 1995;90:97-105. [PubMed: 8975010]

Xiang ZH, Bo XN, Burnstock G. P2X receptor immunoreactivity in the rat cochlea, vestibular ganglion and cochlear nucleus. Hear Res 1999;128:190-196. [PubMed: 10082298]

Yamashita D, Jiang HY, Schacht J, Miller JM. Delayed production of free radicals following noise exposure. Brain Res 2004;1019:201-209. [PubMed: 15306254]

Zhao HB. Connexin26 is responsible for anionic molecule permeability in the cochlea for intercellular signalling and metabolic communications. Eur J Neurosci 2005;21:1859-1868. [PubMed: 15869481]

Zhao HB, Yu N, Fleming CR. Gap junctional hemichannel-mediated ATP release and hearing controls in the inner ear. Proc Natl Acad Sci U S A 2005;102:18724-18729. [PubMed: 16344488]

Zimmermann H. Ectonucleotidase: some recent developments and a note on nomenclature. Drug Dev Res 2001;52:44-56.

\section{Abbreviations}

ADP

adenosine diphosphate

ATP

adenosine triphosphate

E-NPP

ectonucleotide pyrophosphatase/phosphodiesterase

E-NTPDase

ectonucleoside triphosphate diphosphohydrolase

MARCKS

myristoylated alanine-rich C-kinase substrate

OSC

outer sulcus cells

$\mathbf{I}_{\text {sc }}$

inner sulcus cells

$\mathbf{P I P}_{2}$

phosphatidylinositol-4,5-bisphosphate

$\mathbf{I P}_{3}$

inositol 1,4,5-trisphosphate

Hear Res. Author manuscript; available in PMC 2009 January 1. 


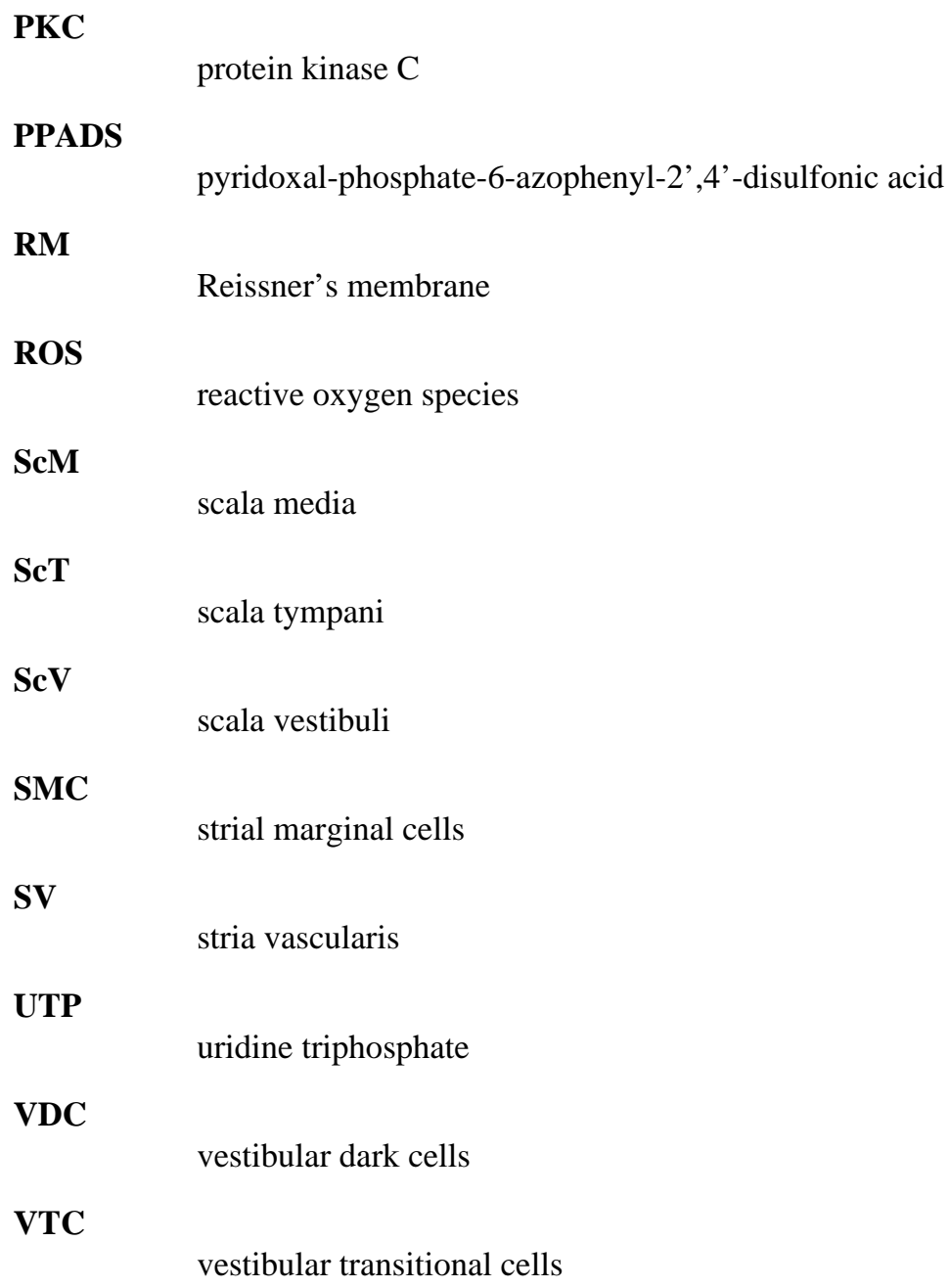


A



C

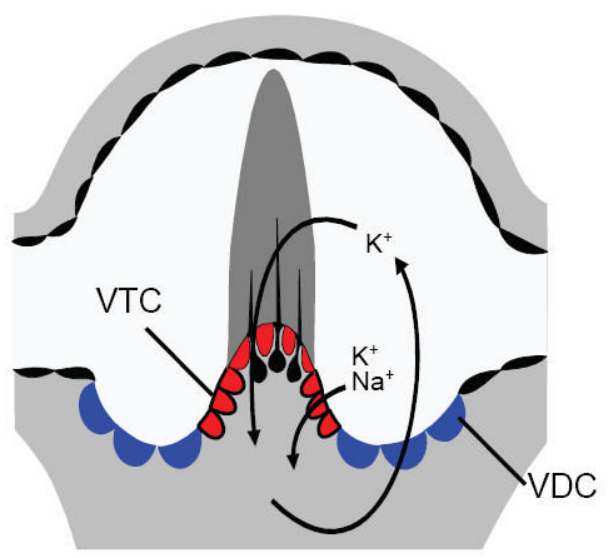

B

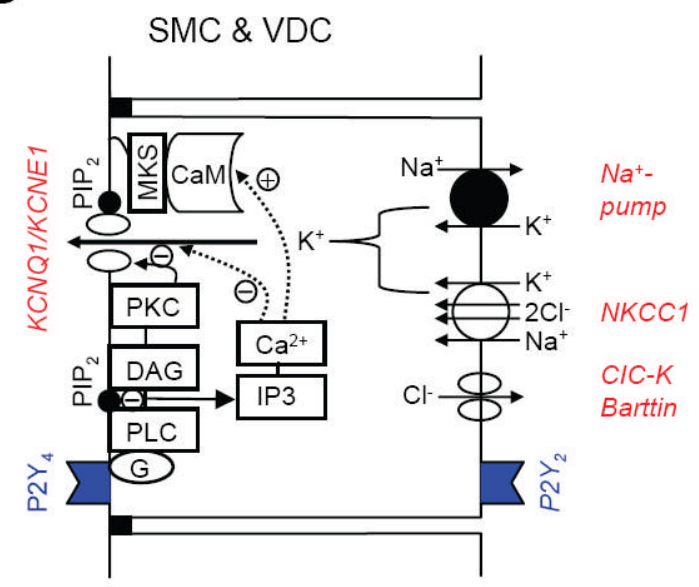

$\mathrm{D}$

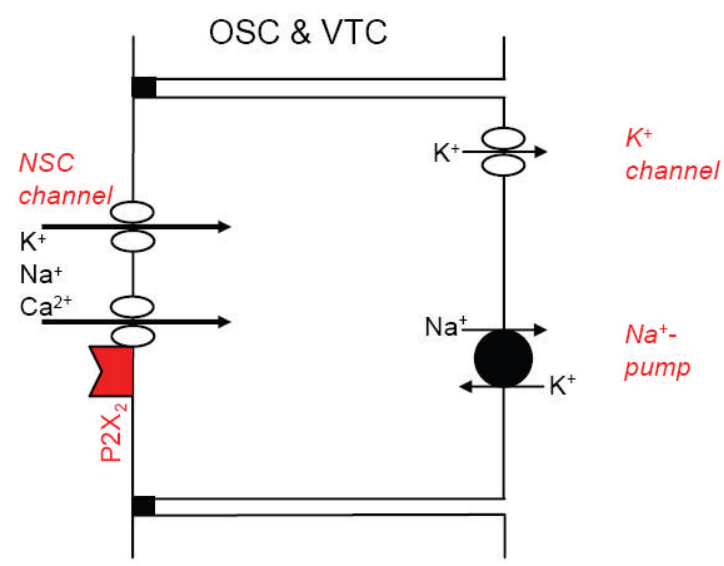

Fig. 1.

Distribution and function of purinergic receptors in the inner ear.

(A) A schematic drawing of the cochlea. The membranous labyrinth of the cochlea, comprised of scala media $(\mathrm{ScM})$ filled with endolymph (high $\mathrm{K}^{+}$, low $\left.\mathrm{Na}^{+}\right)$, and scala vestibuli $(\mathrm{ScV})$ and tympani (ScT) with perilymph (high $\mathrm{Na}^{+}$, low $\mathrm{K}^{+}$). Sound energy delivered to the oval window generates a traveling wave along the cochlear duct. Auditory transduction is initiated by activation of the mechanoelectric transduction channels in the stereocilia of the inner hair cells through which endolymphatic $\mathrm{K}^{+}$enters. Depolarization of inner hair cells leads to $\mathrm{Ca}^{2+}$ influx via voltage-gated $\mathrm{Ca}^{2+}$ channels at the basolateral membrane and subsequent release of neurotransmitter to the afferent dendrites of the spiral ganglion. Three rows of outer hair cells also utilize $\mathrm{K}^{+}$in response to sound and provide an amplification mechanism to the inner hair cells. $\mathrm{K}^{+}$used by the inner and outer hair cells recycles to ScM by diffusion through perilymph to the lateral wall and has been proposed to also move through medial (inner sulcus cells; ISC) and/or lateral gap junction pathways (dotted arrows; reviewed in Wangemann, 2006). The strial marginal cells (SMC) in the stria vascularis (SV) secrete $\mathrm{K}^{+}$, which is the substrate for auditory transduction. The outer sulcus cells (OSC) provide pathways for parasensory cationic absorption. $\mathrm{Na}^{+}$is also extruded from the endolymph to perilymph via epithelial $\mathrm{Na}^{+}$channels in Reissner's membrane ( $\mathrm{RM}) . \mathrm{P}_{2} \mathrm{X}_{2}$ purinergic receptors are expressed in many of the epithelial cells bordering endolymph (red cells) except stria vascularis where apical $\mathrm{P}_{2} \mathrm{Y}_{4}$ and basolateral $\mathrm{P}_{2} \mathrm{Y}_{2}$ purinergic receptors are expressed (blue cells). $\mathrm{P} 2 \mathrm{X}_{2}$ expressed at the 
stereocilia of the hair cells, afferent dendrites of spiral ganglion, and body of spiral ganglion is not shown.

(B) Schematic diagram of modulation of $\mathrm{K}^{+}$secretion by $\mathrm{P}_{2} \mathrm{Y}_{4}$ receptors in SMC and vestibular dark cells (VDC). The pathways are described in the text. Membrane transporters are labeled in red font; P2Y receptors in blue font. G, heterotrimeric G protein; PLC, phospholipase C; $\mathrm{PIP}_{2}$, phosphatidylinositol-4,5-bisphosphate; DAG, diacylglycerol; IP3, inositol 1,4,5trisphosphate; PKC, phosphokinase C; CaM, calmodulin; MKS, myristoylated alanine-rich Ckinase substrate (MARCKS).

(C) A schematic drawing of the ampulla of the semicircular canal. The vestibular system consists of three semicircular canals, saccule, and utricle. The hair cells in the ampulla of the semicircular canal detect angular acceleration, and the ones in the saccule and utricle detect linear acceleration. The VDC and vestibular transitional cells (VTC) have homology with SMC and OSC, respectively, in terms of the ion transport mechanisms and purinergic signaling. $\mathrm{P} 2 \mathrm{X}_{2}$ is expressed in VTC and the supporting cells surrounding the hair cells (red cells). In VDC, $\mathrm{P}_{2} \mathrm{Y}_{4}$ is expressed at the apical membrane and $\mathrm{P} 2 \mathrm{Y}_{2}$ is expressed at the basolateral membrane (blue cells).

(D) Ion transport model for OSC and VTC illustrating both ATP-sensitive ( $\mathrm{P}_{2} \mathrm{X}_{2}$ receptor) and ATP-insensitive nonselective cation (NSC) channels in the apical membrane mediating absorption of $\mathrm{Na}^{+}, \mathrm{K}^{+}$and $\mathrm{Ca}^{2+}$ from endolymph. $\mathrm{Na}^{+}$entering the cell through these channels is removed across the basolateral membrane by the $\mathrm{Na}^{+}$-pump. $\mathrm{K}^{+}$entering the cell via these apical channels and via the $\mathrm{Na}^{+}$-pump diffuse out of the cell through the basolateral $\mathrm{K}^{+}$channel (A and $\mathbf{C}$ adapted from (Wangemann, 2002).) 